DOI

๑О. В. Кравченко, С. В. Печеряга

Вищий державний навчальний заклад Украйни «Буковинський державний медичний університет», Чернівці

\title{
ОЦІНКА ЕФЕКТИВНОСТІ ПРОФІЛАКТИКИ ПЕРВИННОЇ ПЛАЦЕНТАРНОЇ ДИСФУНКЦІЇ В РАННІ ТЕРМІНИ ГЕСТАЦІї ПРИ АНОМАЛЬНОМУ РОЗТАШУВАННІ ПЛАЦЕНТИ
}

ОЦІНКА ЕФЕКТИВНОСТІ ПРОФІЛАКТИКИ ПЕРВИННОЇ ПЛАЦЕНТАРНОЇ ДИСФУНКЦІЇ В РАННІ ТЕРМІНИ ГЕСТАЦІЇ ПРИ АНОМАЛЬНОМУ РОЗТАШУВАННІ ПЛАЦЕНТИ. Проаналізований перебіг вагітностей та пологів 64 вагітних із низьким розташуванням хоріона, яким проводилася профрілактика диссрункції плаценти в ранніх термінах гестації, та 55 жінок із низькою плацентацією, яким не були призначені профрілактичні заходи. Встановлено, що з метою покращення прогнозу перебігу вагітності, а також профрілактики ускладнень в II та III триместрах гестації слід проводити лікувально-профрілактичні заходи, які спрямовані на попередження формування порушень фетоплацентарного комплексу в ранніх термінах вагітності.

ОЦЕНКА ЭФФЕКТИВНОСТИ ПРОФИЛАКТИКИ ПЕРВИЧНОЙ ПЛАЦЕНТАРНОЙ ДИСФУНКЦИИ В РАННИЕ СРОКИ ГЕСТАЦИИ ПРИ АНОМАЛЬНОМ РАСПОЛОЖЕНИИ ПЛАЦЕНТЫ. ПроанаЛИЗИрован ХОД беременностеЙ и родов 64 беременных с низким расположением хориона, которым проводилась профилактика диссрункции плаценты в ранние сроки гестации, и 55 женщин с низкой плацентацией, которым не были назначены профилактические мероприятия. Установлено, что с целью улучшения прогноза течения беременности, а также профилактики осложнений во II и III триместрах гестации следует проводить лечебно-профилактические мероприятия, направленные на предупреждение формирования нарушений фетоплацентарного комплекса в ранних сроках беременности.

PREVENTION EFFICIENCY EVALUATION OF PRIMARY PLACENTAL DYSFUNCTION IN EARLY TERMS OF GESTATION AT ABNORMAL PLACEMENT OF PLACENTA. We analyzed the course of pregnancy and childbirth of 64 pregnant women with a low location of the chorion which conducted prevention dysfunction of the placenta in early stages gestation and 55 women with low placentation, which were not designed preventive measures. It was established that in order to improve the prognosis of pregnancy and prevention of complications in the second and third trimesters of gestation should be preventive measures which aimed at preventing violations of forming placenta in early stage of pregnancy.

Ключові слова: низьке розташування хоріона, плацентарна диссункція, I триместр гестації.

Ключевые слова: низкое расположение хориона, плацентарная дисфункция, I триместр гестации.

Key words: low location chorion, placental dysfunction, I trimester of gestation.

ВСтУп. Частота низької плацентації в І триместрі вагітності складає 24-30 \% випадків [1, 5]. При аномальному розміщенні плаценти, за даними ряду авторів, розвивається фетоплацентарна диссункція, яка обумовлена відносно низькою васкуляризацією нижніх відділів матки $[1,2]$. Перебіг вагітності при низькій плацентації з ранніх термінів гестації характеризується такими клінічними ознаками, як загроза переривання вагітності та кровотечі $[2,3,6]$.

Враховуючи той фракт, що, у вагітних із низьким розташуванням хоріона та кров'янистими виділеннями в I триместрі гестації в подальшому спостерігається висока частота ускладнень вагітності та пологів [3, 4], розробка методів профрілактики плацентарної дисфрункції при даній патології $€$ досить актуальною.

Метою нашого дослідження було розробити комплекс лікувально-профрілактичних заходів, спрямованих на профрілактику первинної плацентарної дисфункції при аномальній плацентації.

МАТЕРІАЛИ ТА МЕТОДИ. Під нашим спостереженням перебували 119 вагітних із низьким розташуванням хоріона. Основна група - 64 вагітних із низьким розташуванням хоріона, яким проводилася профілактика дисфункції плаценти з ранніх термінів гестації, друга група контрольна - 55 жінок із низькою плацентацією, які не отримували профрілактичну терапію.

Жінкам основної групи був запропонований профрілактичний комплекс, який включав: гестагени (лютеїна) в дозі по 50-100 мг два рази на день, екстракт гінкго білоба по 40 мг тричі на день, ериніт по 10 мг тричі на день, фроліо 1 табл. на день, біолектра по 1 табл. в день. Курс лікування негормональної терапії складав 12-14 днів і призначався, починаючи з 5-го - 8-го тижня вагітності по 16 тиждень вагітності. Курс повторювався 2-3 рази з інтервалом 1012 днів. Терміни лікування було обрано з урахуванням особливостей ембріо- і плацентогенезу та загальноприйнятих «критичних періодів» гестації. Гестагенотерапія проводилась до завершення періоду плацентації. Жінки з контрольної групи отримували тільки фролієву кислоту та вітамін Е (відповідно до наказу МОЗ України № 417).

Для оцінки есрективності запропонованої терапії у досліджуваних групах нами проаналізований перебіг вагітностей в ранніх та пізніх термінах гестації, а також ускладнення пологів.

Для статистичної обробки даних використовувалася комп'ютерна програма Microsoft Excel 2013. Розбіжності між групами дослідження обчислені за двостороннім непарним критерієм Стьюдента. 
РЕЗУЛЬТАТИ ДОСЛІДЖЕННЯ ТА ЇХ ОБГОВОРЕННЯ.

Провівши аналіз, ми виявили, що частота ускладнень вагітності в основній групі, де проводилася профрілактика плацентарної дисорункції з ранніх термінів гестації, була значно меншою, ніж у групі контролю. А саме загроза переривання вагітності 3 кровотечею зустрічалась в основній групі 12,5\%, в контрольній - 23,6 \% (p<0,05). Загроза втрати вагітності без кровотечі, відповідно, 29,7 \% i $56,4 \%(p<0,05)$.

В II та III триместрах гестації зберігалися такі самі тенденції. Так, у жінок основної групи в III триместрі гестації ми спостерігали загрозу передчасних пологів в 12,5 3,0 \% випадків, у контрольній групі даний показник стано-

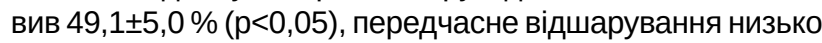
розташованої плаценти було відмічено у 6,3 \% проти $14,5 \%$ в контролі $(p<0,05)$, плацентарна диссрункція - в $18,8 \%$ проти 49,1 \% ( $<<0,05)$, синдром затримки розвитку плода - 4,7 \% проти 14,6 \% (p<0,05) в контролі. Дистрес плода під час вагітності зустрічався в 10,9 \% випадків у жінок основної групи, в контрольній - 32,7 \% (p<0,05).

У пацієнток з аномальною плацентацією термінових пологів було 93,75 \% (60), передчасних - 6,25 \% (4). В контролі частота термінових пологів складала 83,6 \% (46), передчасних пологів - 16,4 \% (9). В основній групі також в 4,4 раза рідше пологи були патологічними $(p<0,05)$.

Був проведений аналіз пологів залежно від терміну гестації. Встановлено, що у 1,8 \% (1) випадків у пацієнток без проорілактики плацентарної дисфункції пологи відбулися у терміні 28-30 тижнів гестації, в основній груп передчасних пологів в даному терміні гестації взагалі не було. Найбільша кількість передчасних пологів була в терміні 34-36 тижнів вагітності, в основній даний показник склав 3,1\% (2), у контрольній - 9,1\% (5).

Звертає на себе увагу значно менший відсоток операцій кесарського розтину в основній групі, порівняно 3 контролем, відповідно, 7,8 \% і $20 \%($ р<0,05). В $100 \%$ випадків у вагітних основної групи операцію кесарського розтину проводили в плановому порядку, порівняно з контрольною групою, де даний показник склав 55,5 \% випадків.

У контрольній групі в пологах передчасне відшарування плаценти зустрічалося в 3,6 \%, дистрес плода - в $5,5 \%$, що слугувало показанням до розродження шляхом ургентного кесарського розтину. Слід відмітити, що в основній групі даних ускладнень в пологах не було.

В основній групі виконано 6 операцій кесарського розтину з приводу клінічного вузького таза, поперечного положення плода, сідничного передлежання і 3 операції - рубець на матці та відмова жінки від спроби вагінальних пологів. Крововтрата склала в середньому 600 мл. Під час операції кесарського розтину в контрольній групі величина середньої крововтрати була вищою і становила 950 мл $(p<0,05)$.

У пацієнток без профрілактики ПД у помірній асорікciї (4-5 балів за шкалою Апгар) народилися 5 (9,1\%) новонароджених. В основній групі цей показник був 2 (3,1 \%) дітей. Тяжка ассріксія (3 бали) спостерігалася в контрольній групі у 2 дітей (3,6 \%). У задовільному стані, 3 оцінкою за шкалою Апгар 7-9 балів у даній групі, народилися всього 48 (87,3 \%). У пацієнток основної групи дітей народжених в асфріксії тяжкого ступеня не було. Переважна більшість новонароджених 62 (95,4 \%) була оцінена за шкалою Апгар 7-9 балів.

Висновок. Проведені дослідження показали, що 3 метою покращення прогнозу перебігу вагітності, а також профрілактики ускладнень в II та III триместрах гестації слід проводити лікувально-профрілактичні заходи, які спрямовані на попередження фрормування порушень сретоплацентарного комплексу в ранніх термінах вагітності.

ПЕРСПЕКТИВИ ПОДАЛЬШИХ ДОСЛІДЖЕНЬ. ПЛАнується вивчення доплерометричних показників кровотоку в хоріоні у вагітних із низькою плацентацією в ранні терміни гестації.

\section{СПИСОК ЛІТЕРАТУРИ}

1. Акушерские и перинатальные аспекты аномалий расположения плаценты / В. С. Горин, Д. А. Лапицкий, Л. А. Бирюкова [и др.] // Вестник НГУ. Серия: Биология, клиническая медицина. - 2008. - Т. 6, вип. 3, ч. 1. - С. 115-126.

2. Минкин Р. И. Влияние аномалий расположения плаценты на течение беременности и исход родов / Р. И. Минкин, Э. Р. Минкина, А. 3. Юнусова // Медицинский альманах. - 2008. - № 5. - С. 63-65.

3. Медянникова И. В. Акушерские и перинатальные аспекты аномальной плацентации : автореф. дисс. на соискание науч. степени канд. мед. наук : спец. 14.01.01 «Акушерство та гинекология» / И. В. Медянникова. - Пермь, 2007. - 22 с.
4. Мяделец И. А. Факторы риска предлежания хориона и нарушения его миграции во втором триместре / И. А. Мяделец // Вест. НГУ. Серия «Биология». - 2011. - Вып. 2. - C. 253.

5. Протопопова Т. А. Тактика ведения беременных и принципы родоразрешения при предлежании и миграции плаценты / Т. А. Протопопова // Рос. мед. журн. - 2003. № 5. - C. 48-50.

6. Israel A. The effect of placenta previa localisation upon maternal and fetal-neonatal outcome / A. Israel, J. A. Gorodeski, C. M. Bahari // J. Perinat. Med. - 1997. Vol. 15. - P. 169-174. 